\title{
Identification of bovine trophoblast protein-1, a secretory protein immunologically related to ovine trophoblast protein-1*
}

\author{
S. D. Helmer†, P. J. Hansen $\ddagger$, R. V. Anthony§ף, W. W. Thatcher*, \\ F. W. Bazer†† and R. M. Roberts§
}

Departments of $\dagger$ Dairy Science, $\ddagger$ Reproduction, $\dagger \dagger$ Animal Science, and $\S$ Biochemistry and Molecular Biology, University of Florida, Gainesville, Florida 32611, U.S.A.

\begin{abstract}
Summary. This paper demonstrates that a group of proteins, representing a major secretory component of cattle conceptuses, is immunologically related to ovine trophoblast protein-1 (oTP-1), a principal product of culture Day 13 to 21 sheep conceptuses. Conceptuses from cows (Day 17-18) and ewes (Day 16-17) were cultured for $24 \mathrm{~h}$ in the presence of $\left.\mathrm{L}-\left.\right|^{3} \mathrm{H}\right]$ leucine. By using a rabbit antiserum to oTP-1 and Ouchterlony double-immunodiffusion analysis it was shown that material in the bovine conceptus culture medium was serologically related, but not identical, to oTP-1. A solid-phase radiobinding assay indicated that the cross-reacting bovine secretory component had an affinity for anti-oTP-1 antibody similar to that of oTP-1. Anti-oTP-1 antiserum specifically immunoprecipitated a group of 6-8 polypeptides from culture medium of cow conceptuses which, when analysed by two-dimensional gel electrophoresis, fell into two major molecular weight classes (22000 and 24000) with isoelectric points between 6.5 and 6.7 . These immunoprecipitated polypeptides, defined as bTP-1, constituted the major secretory products of Day 16-25 cow conceptuses. They were larger and more basic than oTP-1 polypeptides $\left(M_{\mathrm{r}}\right.$ about $\left.18000 ; \mathrm{pI} 5 \cdot 4-5 \cdot 7\right)$. Anti-oTP-1 antiserum also recognized the major translation product of Day 17 bovine conceptus mRNA, a polypeptide significantly smaller $\left(M_{\mathrm{r}} \sim 18000\right)$ than the secreted protein. It is suggested that oTP- 1 and the homologous bovine protein may play similar roles in the phenomenon of maternal recognition of pregnancy in the two species.
\end{abstract}

\section{Introduction}

Embryo transfer experiments have established that maternal recognition of pregnancy in the ewe occurs 12-13 days after onset of previous oestrus (Moor \& Rowson, 1966a, b). The corresponding period for the cow is Day 15-16 (Betteridge et al., 1978; Northey \& French, 1980). In both species the oestrous cycle can be extended significantly if extracts of conceptuses (Rowson \& Moor, 1967; Martal et al., 1979; Ellinwood et al., 1979; Northey \& French, 1980) or trophoblast tissue (Martal et al., 1984a, b; Heyman et al., 1984) are introduced into the uteri of nonpregnant recipients just before this critical period during which maternal recognition of pregnancy occurs. Evidence has accumulated that in the sheep the active substance is proteinaceous and produced for only a limited period, not extending beyond Day 21-23 of pregnancy (Rowson \& Moor, 1967; Martal et al., 1979).

*Reprint requests to Professor R.M. Roberts.

Present address: Department of Animal Sciences, Animal Sciences Center, University of Missouri, Columbia, MO 65211, U.S.A. 
Attention has focussed on one particular secretory protein of the sheep conceptus, ovine trophoblast protein-1 (oTP-1) (Godkin et al., 1984a, b; Hansen et al., 1985). This polypeptide is released as a major product by cultured sheep conceptuses between Days 13 and 21 and is produced maximally around Days 15-17 (Godkin et al., 1982; Hansen et al., 1985). It causes an extension of luteal lifespan when introduced in purified form into the uteri of nonpregnant recipient ewes (Godkin et al., 1984b). The protein consists of a group of 3-4 isoelectric variants (pI 5.4-5.7) of molecular weight $\sim 17000$ (Godkin et al., 1982). Evidence has been presented to indicate that oTP-1 may be a hormone-like substance which acts, in a paracrine manner, on the maternal endometrium (Godkin et al., 1984a).

The conceptuses of cows also release a group of acidic, low molecular weight polypeptides when cultured in vitro. As with oTP-1, their synthesis is limited to a short 7-10-day period (Days 16-26) and coincides with the time at which maternal recognition of pregnancy occurs (Bartol et al., 1985). Introduction of total unfractionated proteins released by cultured bovine conceptuses (bovine conceptus secretory protein; bCSP) into nonpregnant recipient cows causes a significant extension of the interoestrous interval (Knickerbocker et al., 1986). Since the low molecular weight acidic protein is the major component of bCSP, Bartol et al. (1985) have suggested that it may be homologous to oTP-1. In addition, Martal et al. (1984a, b) and Heyman et al. (1984) have shown that transfer of trophoblastic vesicles, comprised of trophectoderm and extraembryonic endoderm derived from Day 11-13-sheep conceptuses, to Day 12 recipient cows resulted in extension of luteal lifespan in a significant number of animals. They also found that reciprocal interspecies transfer of bovine trophoblastic tissue to recipient ewes had a similar effect. Together these results suggest that the trophoblast of ewes and cows produces a functionally similar substance which is recognized by either species. The object of the experiments described in this paper was to determine whether oTP-1 cross-reacts immunologically with component(s) of the bCSP.

\section{Materials and Methods}

Materials. All materials used were supplied by vendors as noted by Godkin et al. (1984a), Bartol et al. (1985) and Hansen et al. (1985).

Animals. Adult crossbred ewes, primarily of Rambouillet breeding, were checked twice daily for oestrus with vasectomized rams. Ewes were mated at behavioural oestrus (Day 0) to two intact rams. Pregnant ewes were anaesthetized and reproductive tracts were exposed by midventral laparotomy. Intact conceptuses were flushed from uteri on Day 16 of pregnancy with a modified minimum essential medium (MEM, see below) at $37^{\circ} \mathrm{C}$ and collected in sterile serum bottles.

Cows and heifers of Holstein, Jersey and crossbred beef breeding from the University of Florida research herds were utilized for collection of bovine conceptuses. The cattle were maintained on pasture and checked for oestrus by using visual observation and bulls with penile shunts. All animals were mated at first observation of oestrus (Day 0) to an intact Brown Swiss bull and artifically inseminated about $12 \mathrm{~h}$ later.

Cows and heifers were slaughtered on Day 17 or 18 after oestrus. Reproductive tracts recovered after exsanguination were placed in plastic bags and transported on ice to a sterile, laminar flow hood where they were trimmed of excess tissue, including the ovaries and oviducts. The cervix was closed by applying a large, curved, RochesterOchsner forcep to the anterior cervix. A plastic, $50-\mathrm{ml}$ syringe fitted with a 16-gauge needle was then used to inject $40 \mathrm{ml}$ sterile minimal essential medium (MEM) into the uterine lumen through the tip of the uterine horn contralateral to the ovary bearing the corpus luteum. The anterior tip (about $1 \mathrm{~cm}$ ) of the horn ipsilateral to the corpus luteum had been removed to provide a enlarged opening. Conceptuses were flushed through this opening into sterile, plastic, culture dishes.

In-vitro culture of conceptuses. After collection, conceptuses from cows and ewes were transferred to sterile plastic culture dishes containing $15 \mathrm{ml}$ fresh MEM and $\left.100 \mu \mathrm{Ci} \mathrm{L-|}{ }^{3} \mathrm{H}\right]$ leucine. Conceptuses were cultured for $24 \mathrm{~h}$ in a controlled atmosphere chamber (Model number 7741-10010, Bellco Biological Glassware, Vineland, NJ, U.S.A.), flushed for $10 \mathrm{~min}$ with $50 \% \mathrm{~N}_{2}: 47 \cdot 5 \% \mathrm{O}_{2}: 2 \cdot 5 \% \mathrm{CO}_{2}$ and maintained at $37^{\circ} \mathrm{C}$ in the dark on a rocking platform. Incubations were terminated by removing conceptuses from culture medium. The medium was frozen at $-20^{\circ} \mathrm{C}$ until used in subsequent studies.

Purification of oTP-1. Ovine TP-1 was purified by the method of Godkin et al. (1982). Purity was confirmed by polyacrylamide gel electrophoresis (Godkin et al., 1982).

Medium preparation. A modified MEM was prepared according to the method of Basha et al. (1979) and used as described by Godkin et al. (1982) for the culture of conceptuses. 
Preparation of conceptus culture medium for analysis. Media from cultured conceptuses were centrifuged at $12000 \mathrm{~g}$ for $10 \mathrm{~min}$ to sediment any cellular material present. Supernatant fractions pooled from several cultures were then dialysed $\left(M_{\mathrm{r}}\right.$ cutoff about 1000$)$ extensively ( 4 litres, changed 4 times) against $10 \mathrm{~mm}-\mathrm{Tris}-\mathrm{HCl}$ buffer $(\mathrm{pH} 8 \cdot 2)$ to remove low molecular weight compounds, e.g. salts and unincorporated radiolabelled precursors. Whenever the protein concentration of a sample was too low for immediate analysis, samples were dialysed $\left(M_{\mathrm{r}}\right.$ cutoff about 1000$)$ against double-distilled water, lyophilized and resolubilized in an appropriate buffer.

Protein determination. Protein concentrations were determined by the method of Lowry et al. (1951) using bovine serum albumin as the standard.

Immunodiffusion techniques. Immunodiffusion plates containing $5 \mathrm{ml} 1 \%(\mathrm{w} / \mathrm{v})$ agarose in $0.07 \mathrm{M}$-sodium phosphate buffer ( $\mathrm{pH} \mathrm{7.4)} \mathrm{were} \mathrm{prepared} \mathrm{in} \mathrm{each} \mathrm{well} \mathrm{of} \mathrm{6-well} \mathrm{tissue} \mathrm{culture} \mathrm{plates} \mathrm{(diameter} 35 \mathrm{~mm}$ ) according to the method of Ouchterlony \& Nilsson (1973). Antibody specificity was determined by placing antiserum raised against oTP-1 in rabbits (Godkin et al., 1984a) in the centre well of each plate. Various dilutions of ovine CSP and bovine CSP were introduced into the outer wells. The plates were placed in a container to maintain a moist atmosphere. Resultant precipitation bands were observed at $2448 \mathrm{~h}$ at room temperature. Plates were extensively washed in Dulbecco's saline (PBS; $0.2 \mathrm{~g} \mathrm{KC1} / 1 ; 2 \cdot 16 \mathrm{~g} \mathrm{KH}_{2} \mathrm{PO}_{4} .7 \mathrm{H}_{2} \mathrm{O} / 1,8 \mathrm{~g} \mathrm{NaCl} / 1$ ). (Dulbecco \& Vogt, 1954) to elute nonprecipitated material, and the bands were stained with Coomassie blue. After destaining the gels were photographed.

Solid-phase radiobinding assay. Bovine conceptus secretory proteins, purified oTP-1 and bovine serum albumin were each adjusted to a concentration of $50 \mu \mathrm{g} / \mathrm{ml}$ in PBS. Anti-oTP-1 antiserum was enriched for immunoglobulins by precipitation with ammonium sulphate and subsequent fractionation on a DEAE-cellulose column (Good et al., 1980). Proteins were eluted with a $150 \mathrm{ml}$ linear salt gradient $(0-0.25 \mathrm{M}-\mathrm{NaCl}$ in $10 \mathrm{~mm}-\mathrm{Tris}-\mathrm{HCl}$ buffer, $\mathrm{pH} 8 \cdot 2)$ and $2.0 \mathrm{ml}$ fractions were collected. The early eluting IgG-rich peak of anti-oTP-1 (fractions 3-19) was pooled and utilized in subsequent steps. Bovine CSP, purified oTP-1 or bovine serum albumin ( $50 \mu \mathrm{l}$ of each per well) were allowed to adsorb passively to the wells of 96-well flexvinyl plates (Falcon brand; Fisher Scientific, Orlando, FL) for $1 \mathrm{~h}$ at room temperature. These protein solutions were withdrawn, and plates washed once with $0 \cdot 1 \%(\mathrm{w} / \mathrm{v})$ bovine serum albumin in PBS (pH 7.4). Anti-oTP-1 antiserum or normal rabbit serum (NRS) was then added at increasing dilutions and allowed to stand in the wells at $4^{\circ} \mathrm{C}$ overnight. These solutions were removed and plates were washed with PBS containing bovine serum albumin. After washing, ${ }^{125} \mathrm{I}$-labelled, sheep anti-rabbit IgG antibody (50 000 c.p.m.; sp. act. $10^{6}$ c.p.m. $/ \mu \mathrm{g}$ ) which had been affinity purified was added to each well and left for $1 \mathrm{~h}$ at room temperature. The unbound labelled second antibody was then removed and the plates washed three times with PBS-bovine serum albumin. Wells were cut from the plates and the amount of bound ${ }^{125}$ I measured.

Immunoprecipitation. Duplicate aliquants of ovine and bovine conceptus culture medium $(80 \mu \mathrm{g}$ and $120 \mu \mathrm{g}$ protein, respectively) were lyophilized and redissolved in immunoprecipitation buffer $[0.35 \mathrm{ml} 0.3 \mathrm{M}-\mathrm{NaCl}, 0.05 \mathrm{M}-\mathrm{Tris}-$ acetate (pH 7.5), $1 \mathrm{~mm}$-pheylmethylsulphonyl fluoride, $1 \mathrm{~mm}$-disodium EDTA, $0.1 \mathrm{mg}$ bovine serum albumin/ml, $0.02 \%(\mathrm{w} / \mathrm{v}) \mathrm{NaN}_{3}$ and $2 \%(\mathrm{v} / \mathrm{v})$ Nonidet $\mathrm{p}-40 \mathrm{l}$. Anti-oTP-1 antiserum $(0.05 \mathrm{ml})$ or normal rabbit serum $(0.05 \mathrm{ml})$ was added to ovine and bovine samples and the tubes were placed on a tube turner overnight at $4^{\circ} \mathrm{C}$. Subsequently, $0.1 \mathrm{ml}$ of a $10 \%(\mathrm{v} / \mathrm{v})$ suspension of Protein A-Sepharose was added to each tube and allowed to incubate for $6 \mathrm{~h}$ at room temperature on a tube turner. The Sepharose suspension was centrifuged ( $15000 \mathrm{~g}$ for $1 \mathrm{~min})$ and washed five times with $1 \mathrm{ml}$ detergent buffer $[0.05 \mathrm{M}$-Tris-acetate $(\mathrm{pH} 7.5), 0.5 \%(\mathrm{v} / \mathrm{v})$ Nonidet $\mathrm{P}-40,0.1 \%$ sodium dodecyl sulphate, $0.3 \mathrm{M}-\mathrm{NaCl}$ and $0.02 \% \mathrm{NaN}_{3}$ ]. Protein absorbed to the gel beads was solubilized in $0.05 \mathrm{ml} 5 \mathrm{~mm}-\mathrm{Tris}-\mathrm{HCl}$ $(\mathrm{pH} 6.8), 15 \%(\mathrm{w} / \mathrm{v})$ glycerol, $5 \%(\mathrm{w} / \mathrm{v})$ sodium dodecyl sulphate and $5 \%(\mathrm{w} / \mathrm{v}) \beta$-mercaptoethanol before onedimensional electrophoresis, or in $0.05 \mathrm{ml} 5 \mathrm{~mm}-\mathrm{K}_{2} \mathrm{CO}_{3}, 5 \mathrm{mg}$ dithiothreitol $/ \mathrm{ml}, 2 \%$ (v/v) Nonidet P-40 and $9.16 \mathrm{M}$-urea before two-dimensional electrophoresis. One-dimensional and two-dimensional polyacrylamide gel electrophoresis (1-D PAGE and 2-D PAGE), using $12 \cdot 5 \%(\mathrm{w} / \mathrm{v})$ acrylamide gels, were performed according to procedures described in detail by Roberts et al. (1984).

Isolation and translation of conceptus $m R N A$. Isolation and translation of conceptus mRNA was accomplished essentially by the methods described by Hansen et al. (1985). Conceptus tissue was homogenized with $1 \mathrm{ml} 4-\mathrm{M}$ guanadinium thiocyanate, $0.5 \%(\mathrm{w} / \mathrm{v})$ sodium $\mathrm{N}$-lauroyl sarcosine, $25 \mathrm{~mm}$-sodium citrate buffer $(\mathrm{pH} 7 \cdot 0$ ), $0 \cdot 1 \mathrm{M}$ 2 -mercaptoethanol and $0.1 \%(\mathrm{v} / \mathrm{v})$ antifoam $\mathrm{A}$, and then precipitated at $-20^{\circ} \mathrm{C}$ with $25 \mu 1 \mathrm{l}$-acetic acid and $750 \mu \mathrm{l}$ absolute ethanol (Chirgwin et al., 1979). The ethanol precipitate was collected by centrifugation (12000 $\mathrm{g}$ ), redissolved in the homogenization buffer (see above), layered over a $5.7 \mathrm{M}$-cesium chloride cushion and centrifuged for $20 \mathrm{~h}$ at $100000 \mathrm{~g}\left(20^{\circ} \mathrm{C}\right)$ to harvest the total cellular RNA (Chirgwin et al., 1979). Polyadenylated RNA was isolated from the total cellular RNA by two cycles of binding to (50 mM-potassium citrate, $\mathrm{pH} 7.5,0.5 \mathrm{M}$-potassium chloride, I mM-disodium EDTA) and elution from (10 mm-potassium citrate, pH 7.5, 1 mM-disodium EDTA) oligodeoxythymidylate cellulose (Aviv \& Leder, 1972).

Translation of conceptus poly $\mathrm{A}^{+}$RNA was accomplished in a cell-free system using wheat-germ lysate (Roberts $\&$ Patterson, 1973). The translation mixture contained $0.25-1.0 \mu \mathrm{g}$ poly $\mathrm{A}^{+} \mathrm{RNA}, 6 \mu \mathrm{l}$ wheat germ lysate, $48 \mathrm{mM}-$ potassium chloride, $27 \mathrm{~mm}$-Hepes (pH 7.5), $67 \mathrm{~mm}$-potassium acetate, $2.7 \mathrm{~mm}$-magnesium acetate, $1.2 \mathrm{~mm}-\mathrm{ATP}$, $100 \mu \mathrm{M}-\mathrm{GTP}, 5.5 \mathrm{~mm}$-creatine phosphate, $200 \mu \mathrm{g}$ creatine phosphokinase $/ \mathrm{ml}, 80 \mu \mathrm{M}$-spermidine phosphate, $1 \mathrm{~mm}-$ $\mathrm{BME}, 50 \mu \mathrm{M}$ each of 19 amino acids (minus methionine), $600 \mu \mathrm{Ci} \mathrm{L}-\left[{ }^{35} \mathrm{~S}\right]$ methionine $/ \mathrm{ml}$ and $13 \cdot 5 \mu \mathrm{g}$ placental RNase inhibitor $/ \mathrm{ml}$ in a total volume of $15 \mu \mathrm{l}$. After translation, the $\left[{ }^{35} \mathrm{~S}\right]$ methionine-labelled products were analysed by one-dimensional PAGE as total translation products or following immunoprecipitation with anti-oTP-1 antiserum $(10 \mu l)$ as described in the preceding section. 


\section{Results}

Ouchterlony double-immunodiffusion analysis

Rabbit antiserum prepared against highly purified oTP-1 gave a single immunopreciptiation band against both oCSP and bCSP (Figs la, b). When the ovine and bovine CSP were placed in adjacent outer wells of the immunodiffusion plate, with the antiserum in the central well, the immunoprecipitation band was discontinuous and had clearly defined spurs (Fig. 2).
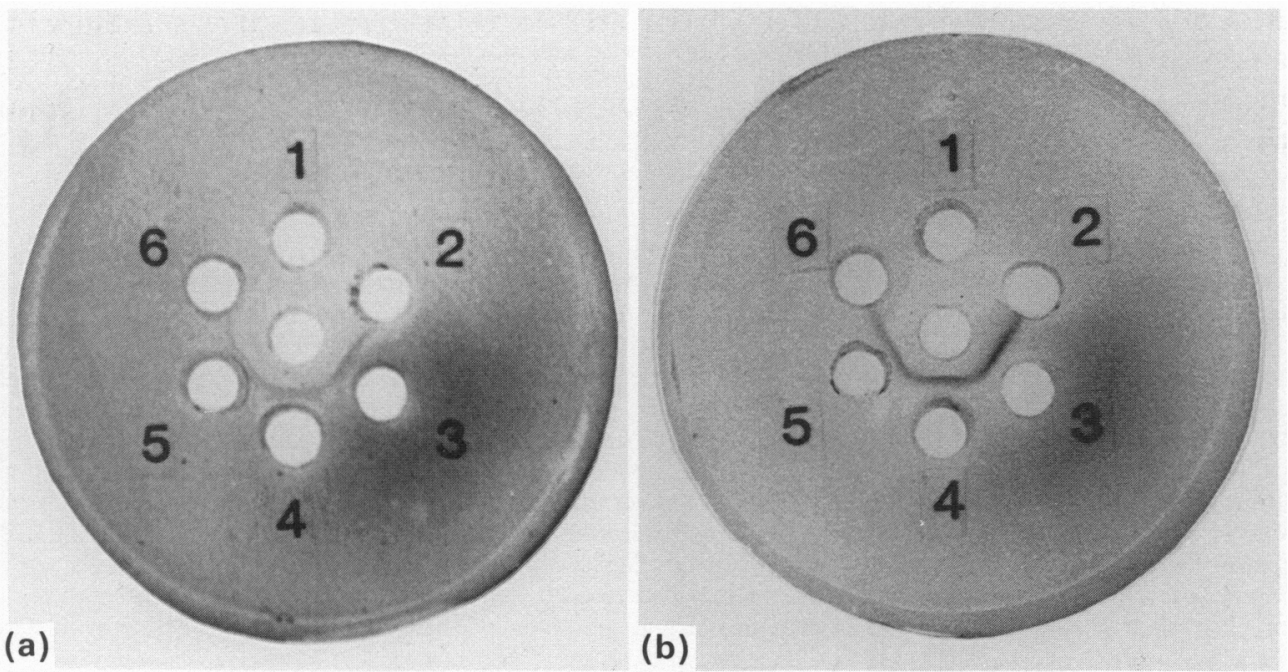

Fig. 1. Ouchterlony double-immunodiffusion analysis of conceptus secretory proteins from (a) sheep and (b) cattle. Total conceptus secretory proteins (a, sheep; b, cattle) $(15 \mu \mathrm{l} ; 1.5 \mu \mathrm{g})$ were placed in the centre well. Phosphate-buffered saline was placed in Well 2 and antiserum to oTP-1 was placed in Wells 3, 4, 5, 6 and 1 at increasing dilutions in phosphate-buffered saline $(1: 3,1: 7,1: 15,1: 31,1: 63)$ respectively.



Fig. 2. Ouchterlony double-immunodiffusion analysis of bovine and ovine conceptus secretory proteins. Anti-oTP-1 antiserum was placed in the centre well (Godkin et al., 1982). Total bovine conceptus secretory proteins were placed in Well $1(30 \mu \mathrm{l}, 6 \mu \mathrm{g})$ and Wells 3 and 5 $(15 \mu \mathrm{l}, 1.5 \mu \mathrm{g})$. Total ovine conceptus secretory proteins were placed in Wells 2,4 and $6(15 \mu \mathrm{l}$, $1.5 \mu \mathrm{g} ; 10 \mu \mathrm{l}, 1.0 \mu \mathrm{g}$ and $7.5 \mu \mathrm{l}, 0.75 \mu \mathrm{g})$ respectively. 


\section{Solid-phase radiobinding assay}

Total bCSP was adsorbed passively to the wells of flexvinyl plates, Anti-oTP-1 antiserum was then added at increasing dilutions and bound immunoglobulin detected by means of ${ }^{125} \mathrm{I}$-labelled sheep antirabbit IgG (Fig. 3). The results confirmed that the anti-oTP-1 antiserum bound to some component in bovine CSP and cross-reacted with purified oTP-1. Only at dilutions of antiserum below 1:20 was there detectable binding of antiserum to bovine serum albumin. We cannot, therefore, exclude the possibility that the antiserum did not show some cross-reactivity towards this protein. Preimmune serum tested over a similar range of dilutions failed to bind either oTP-1 or total bCSP. Half-maximal binding to bCSP and oTP-1 was detected at antiserum dilutions of about 1:80 and 1:160 respectively. The binding curves for these two protein fractions were parallel. At the initial 1:10 dilution of antiserum the wells containing adsorbed oTP-1 bound about twice as much ${ }^{125}$ I-labelled second antibody as did the wells containing bCSP.

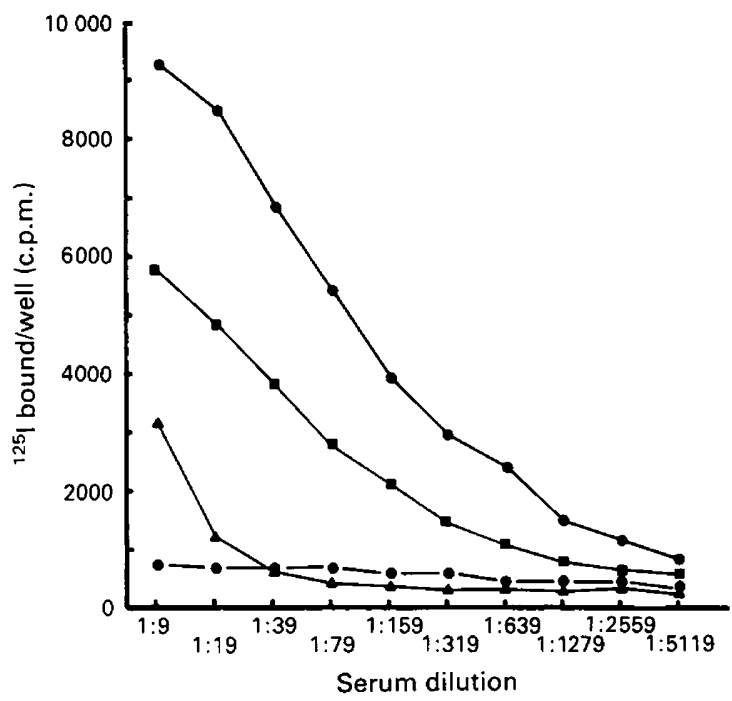

Fig. 3. Solid phase radiobinding assay of conceptus secretory proteins. Anti-oTP-1 antiserum was serially diluted and tested for binding to purified oTP-1 (-- ) bCSPs ( $-\boldsymbol{\square})$, or bovine serum albumin ( $\mathbf{\Delta}-\mathbf{\Delta})$. Normal rabbit serum, used in a control, was serially diluted and tested for binding to purified oTP-1 (not shown), bCSPs (not shown) or bovine serum albumin (-) . Results of curves not shown were approximately 400 c.p.m. greater than the bovine serum albumin-nonimmune rabbit serum at a 1:10 dilution and were similar at greater dilutions. Binding was measured by means of a ${ }^{125} \mathrm{I}$-labelled sheep anti-rabbit IgG.

\section{Immunoprecipitation of polypeptides from ovine and bovine CSP}

Sheep and cattle conceptuses were incubated in the presence of $L-\left[{ }^{3} \mathrm{H}\right]$ leucine and cross-reacting polypeptides in the dialysed culture medium immunoprecipitated by successive addition of anti-oTP-1 antiserum and protein A-Sepharose. For oCSP, the antiserum specifically cross-reacted with polypeptide(s) with an $M_{\mathrm{r}}$ about 18000 (Fig. 4). With bCSP, two bands of polypeptides were detected by one-dimensional polyacrylamide gel analysis. These bands had apparent molecular weights of 22000 and 24000 (Fig. 4).

When the polypeptides from bCSP (Fig. 5) were immunoprecipitated and analysed by twodimensional PAGE, at least 8 polypeptides could be visualized on fluorographs (Fig. 6). The majority of these were localized in two parallel rows of apparent $M_{\mathrm{r}} 22000$ and 24000 . Their approximate isoelectric points ranged from 6.7 to 6.5 (Fig. 6). These polypeptides were the major components present on gels of total bCSP at Day 17 of pregnancy (Fig. 5). 


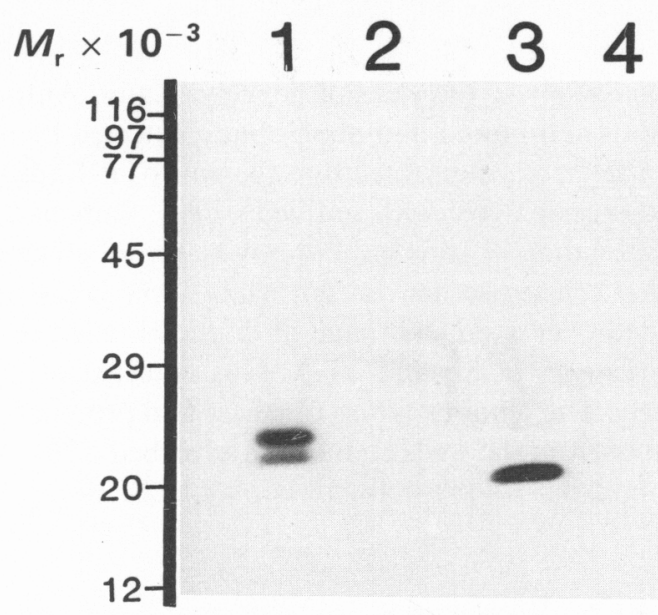

Fig. 4. Analysis of immunoprecipitates from conceptus secretory proteins of cows and sheep by one-dimensional polyacrylamide gel electrophoresis and fluorography. Lanes 1 and 3 contained material from bCSPs and oCSPs respectively, which had been immunoprecipitated by means of anti-oTP-1 antiserum followed by Protein A-Sepharose. Lanes 2 and 4 were control lanes in which bCSPs and oCSPs, respectively, had been treated with normal rabbit serum followed by Protein A-Sepharose.

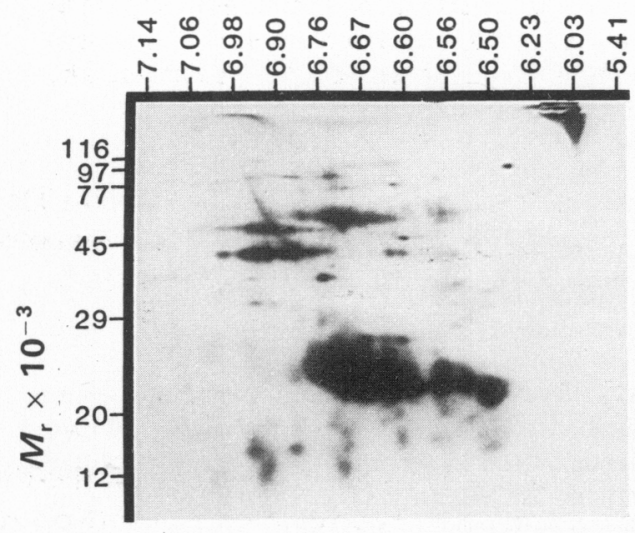

Fig. 5

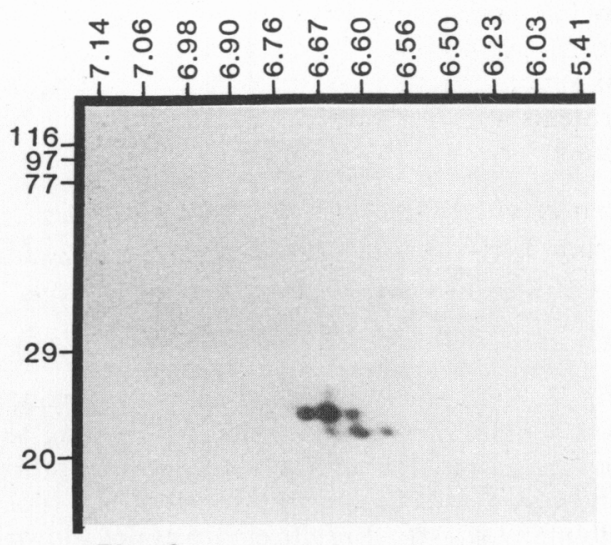

Fig. 6

Fig. 5. Analysis of bovine CSP by two-dimensional polyacrylamide gel electrophoresis and fluorography. Horizontal scale represents $\mathrm{pI}$ values.

Fig. 6. Analysis of immunoprecipitable material from bovine CSP by two-dimensional polyacrylamide gel electrophoresis and fluorography. Bovine CSP was treated with anti-oTF-1 antiserum, immune complexes were collected on Protein A-Sepharose and the radioactive proteins analysed.

\section{Immunoprecipitation of polypeptides from in-vitro translation products}

Total poly $(\mathrm{A})^{+}$conceptus mRNA was translated in vitro in a wheat-germ translation system in which $\mathrm{L}-\left[{ }^{35} \mathrm{~S}\right]$ methionine was provided as a source of labelled amino acid. The products of translation were analysed by one-dimensional PAGE and fluorography. Translation of bovine mRNA gave rise to a range of translation products with molecular weights ranging from 130000 to 12500 (Fig. 7). With the sheep system, the dominant translation product had an $M_{\mathrm{r}}$ of about 21000 


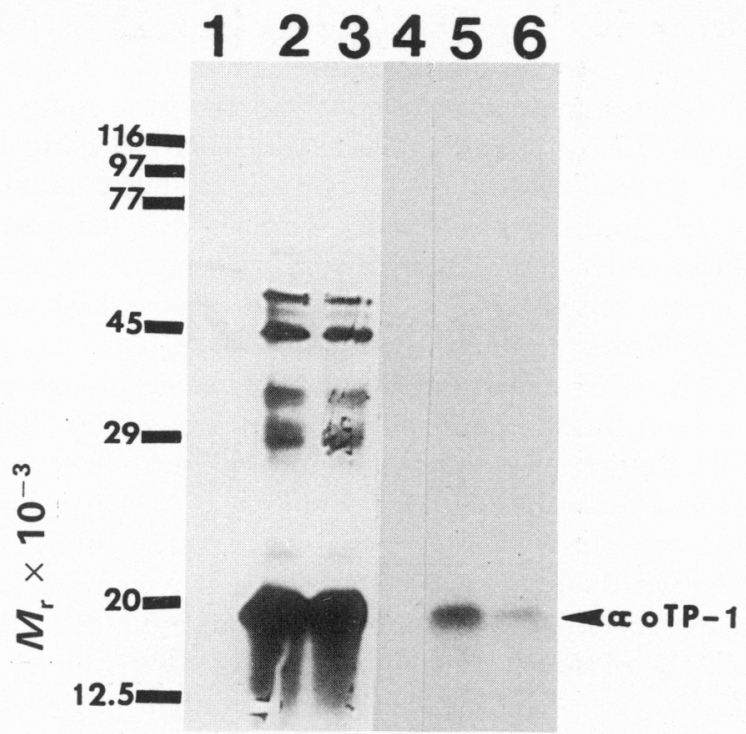

Fig. 7. Electrophoretic analysis of cell-free translation products of RNA isolated from cattle conceptuses. Lane 1 represents total translation products when no bovine mRNA was present. Lanes 2 and 3 show translation products when total poly $(\mathrm{A})^{+}$bovine conceptus mRNA was used as a source of exogenous mRNA. Lane 4 shows the material that was immunoprecipitated from such products by using normal rabbit serum. Lanes 5 and 6 show material that was immunoprecipitated from the total translation mixture by using anti-oTP-1 antiserum. The proteins were analysed in $12.5 \%$ polyacrylamide gels and detected by fluorography.

(Hansen et al., 1985) and this component was specifically immunoprecipitated with anti-oTP-1 antiserum. For cow conceptus mRNA a dominant translation product of $M_{\mathrm{r}}$ about 18000 was noted which cross-reacted with anti-oTP-1 antiserum.

\section{Discussion}

A considerable body of evidence has accumulated to suggest that the mechanisms involved in maternal recognition of pregnancy and luteal maintenance in the ewe and cow are similar (Roberts et al., 1985; Bazer et al., 1986; Thatcher et al., 1986). Secretory components, proteinaceous in nature, are thought to be involved as antiluteolytic substances in both species. These substances probably act locally on the uterine endometrium and, by mechanisms still not understood, reduce the pulsatile release of the presumed uterine luteolysin prostaglandin $F-2 \alpha$, from the gravid uterine horn (Thatcher et al., 1986; Fincher et al., 1985; Knickerbocker et al., 1986). Other antiluteolytic, luteoprotective and luteotrophic mechanisms may also be regulated by these unique proteins secreted by the conceptus (Thatcher et al., 1986).

In both the ewe and cow, low molecular weight acidic proteins are major components of the conceptus secretions during the critical time that the corpus luteum is rescued. The question has arisen as to whether these proteins are antiluteolytic, either alone or in combination with other conceptus products. Until the present study these low molecular weight acidic polypeptides produced by the ewe and cow conceptus had not been compared.

Ouchterlony double immunodiffusion analysis clearly showed that antiserum to oTP-1 crossreacted immunologically with some component(s) in bCSP. When ovine and bovine conceptus secretory proteins were placed in adjacent outer wells, with the antiserum to oTP-1 located in the central wall, the fusion of immunoprecipitation lines was incomplete and spurs were evident. This 
indicates that a protein is present in bCSP which is not identical to oTP-1 but is related serologically to it. This result was confirmed by the solid-phase radiobinding assay which showed that half-maximal binding of antiserum to adsorbed oTP-1 occurred at about twice the antiserum dilution as observed with bCSP. The protein serologically related to oTP-1 in bCSP was clearly present as a high proportion of the total protein. In addition, the binding curves obtained with increasing antiserum dilutions were parallel, a result which suggests that the relative affinity of antibody towards oTP-1 and the cross-reacting protein in bCSP is similar. The fact that the antiserum did not bind strongly to bovine serum albumin in the solid-phase radiobinding assay (Fig. 3 ) or to serum proteins (R. M. Roberts, unpublished results) indicated that the reaction between bCSP and antiserum was not directed nonspecifically towards some plasma component. Neither has cross-reactivity been demonstrated against polypeptides released by Day 12-14 pig conceptuses (unpublished results). The antiserum does not therefore appear to have broad cross-reactivity with trophoblast proteins from all species.

Anti-oTP-1 antiserum specifically immunoprecipitated a group of 6-8 polypeptides from bCSP which, when analysed by two-dimensional PAGE, fell into two major molecular weight classes $\left(M_{\mathrm{r}}\right.$ $22000,24000)$. A trace of an $M_{\mathrm{r}} 26000$ component was also present. These bovine polypeptides were slightly more basic and of significantly higher molecular weight than the previously described oTP-1 components (Godkin et al., 1982). The fact that only a single molecular weight band of protein is immunoprecipitated from cell-free translation of bovine poly (A) ${ }^{+}$mRNA by anti-oTP-1 antiserum suggests that the heterogeneity in molecular size of the bovine protein may be the result of some degree of post-translational processing of the initial translation product. This cell-free translation product has a molecular weight 4000-6000 less than the products immunoprecipitated from bCPS. This is in contrast to the immunoprecipitable translation product for ovine poly $\left(\mathrm{A}^{+}\right)$ mRNA, in which the translation product has a molecular weight of 4000 larger than the products immunoprecipitated from oCSP (Hansen et al., 1985). These differences suggest that the posttranslation processing of the ovine and bovine proteins is dissimilar. One possible explanation is that the bovine proteins are glycosylated whereas the ovine protein simply undergoes proteolytic cleavage, e.g. removal of a signal sequence, with no glycosylation.

In conclusion, results of this study demonstrate that the cow conceptus secretes a protein complex that is immunologically related to oTP-1. This protein complex is a major product released by Day 16-26 cow conceptuses during the critical period at which the corpus luteum has to be protected from the luteolytic action of uterine PGF-2 $\alpha$ (Bartol et al., 1985). Because of this immunological similarity and because it is synthesized at a developmentally equivalent stage of pregnancy as oTP-1, we suggest that the protein complex secreted by the bovine conceptus which cross-reacts with antiserum to oTP-1 should be called bovine trophoblast protein-1 (or bTP-1). We predict that oTP-1 and bTP-1 may play functionally similar roles in maternal recognition of pregnancy in the two species. Finally, provided there is no cross-reactivity with plasma proteins in the culture medium, anti-oTP-1 antiserum is likely to prove a valuable reagent in further studies on bTP-I, a protein which has so far resisted attempts at purification by conventional means.

We thank Ms Carol Underwood, Dr Jeffrey Knickerbocker and Mr John McDermot for technical assistance, and $\mathrm{Mr}$ John Berceann for typing this manuscript. The research was supported by grants from National Institutes of Health (HD10436), U.S. Department of Agriculture (85CRCR-1-1871), and the Upjohn Company. R.V.A. was supported by a NIH-NRSA postdoctoral fellowship (HD06766). This paper is Journal Series No. 7066 of the Florida Agricultural Experiment Station.

\section{References}

Aviv, H. \& Leder, P. (1972) Purification of biologically active globin messenger RNA by chromatography on oligothymidylic acid-cellulose. Proc. natn. Acad. Sci. U.S.A. 69, 1408-1412.
Bartol, F.F., Roberts, R.M., Bazer, F.W., Lewis, G.S., Godkin, J.D. \& Thatcher, W.W. (1985) Characterization of proteins produced in vitro by periattachment bovine conceptuses. Biol. Reprod. 32, 681-693. 
Basha, S.M.M., Bazer, F.W. \& Roberts, R.M. (1979) The secretion of a uterine specific, purple phosphatase by cultured explants of porcine endometrium dependency upon the state of pregnancy of the donor animal. Biol. Reprod. 20, 431-441.

Bazer, F.W., Vallet, J.L., Roberts, R.M., Sharp, D.C. \& Thatcher, W.W. (1986) Role of conceptus secretory products in establishment of pregnancy. $J$. Reprod. Fert. 76, 841-850.

Betteridge, K.J., Eaglesome, N.D., Randall, G.C.B. Mitchell, D. \& Lugden, E.A. (1978) Maternal progesterone levels as evidence of luteotrophic or antiluteolytic effects on embryos transferred to heifers 12-17 days after estrus. Theriogenology 9, 86-93.

Chirgwin, J.M., Przybyla, A.E., MacDonald, R.J. \& Rutter, W.J. (1979) Isolation of biologically active ribonucleic acid from sources enriched in ribonuclease. Biochemistry, N.Y. 18, 5294-5299.

Dulbecco, R. \& Vogt, M. (1954) Plaque formation and isolation of pure lines of poliomyelitis viruses. $J$. exp. Med. 99, 167-182.

Ellinwood, W.E., Nett, T.M. \& Niswender, G.D. (1979) Maintenance of the corpus luteum of early pregnancy in the ewe. I. Luteotropic properties of embryonic homogenates. Biol. Reprod. 21, 281-288.

Fincher, K.B., Bazer, F.W., Hansen, P.J., Thatcher, W.W. \& Roberts, R.M. (1985) Ovine conceptus secretory proteins suppress induction of uterine prostaglandin $\mathrm{F} 2 \alpha$ release by oestradiol and oxytocin. $J$. Reprod. Fert. 76, 425-433.

Godkin, J.D., Bazer, F.W., Moffatt, J., Sessions, F. \& Roberts, R.M. (1982) Purification and properties of a major, low molecular weight protein released by the trophoblast of sheep blastocysts at Day 13-21.J. Reprod. Fert. 65, 141-150.

Godkin, J.D., Bazer, F.W. \& Roberts, R.M. (1984a) Ovine trophoblast protein-1, an early secreted blastocyst protein, binds specifically to uterine endometrium and affects protein synthesis. Endocrinology 114, $120-130$.

Godkin, J.D., Bazer, F.W., Thatcher, W.W. \& Roberts, R.M. (1984b) Proteins released by Day 15-16 conceptuses prolong luteal maintenance when introduced into the uterine lumen of cyclic ewes. $J$. Reprod. Fert. 71, 57-64.

Good, A.H., Wofsy, L., Kimura, J. \& Henry, C. (1980) Purification of immunoglobulins and their fragments. In Selected Methods in Cellular Immunology, pp. 278-286. Eds B. B. Mishell \& S. M. Shiigi. W. H. Freeman \& Co., San Francisco.

Hansen, P.J., Anthony, R.V., Bazer, F.W., Baumbach, G.A. \& Roberts, R.M. (1985) In vitro synthesis and secretion of ovine trophoblast protein-1 during the period of maternal recognition of pregnancy. Endocrinology 117, 1424-1430.

Heyman, Y., Camous, S., Févere, J., Méziou, W. \& Martal, J. (1984) Maintenance of corpus luteum after uterine transfer of trophoblastic vesicles to cyclic cows and ewes. J. Reprod. Fert. 70, 533-540.

Knickerbocker, J.J., Thatcher, W.W., Bazer, F.W., Drost, M., Barron, D.H., Fincher, K.B. \& Roberts, R.M. (1986) Proteins secreted by Day-16 to -18 bovine conceptuses extend corpus luteum function in cows. J. Reprod. Fert. 77, 381-391.
Lowry, O.H., Rosebrough, N.J., Farr, A.L. \& Randall, R.J. (1951) Protein measurement with the Folin phenol reagent. J. biol. Chem. 193, 265-275.

Martal, J., Lacroix, M.-C., Loudes, C., Saunier, M. \& Wintenberger-Torres, S. (1979) Trophoblastin, an antiluteolytic protein present in early pregnancy in sheep. J. Reprod. Fert. 56, 63-73.

Martal, J., Camous, S., Févre, J., Charlier, M. \& Heyman, Y. (1984a) Specificity of embryonic signals maintaining corpus luteum in early pregnancy in ruminants. Proc. 10th Int. Congr. Anim. Reprod. \& A.I., Urbana 3, 510, Abstr.

Martal, J., Charlier, M., Camous, S., Févre, J. \& Heyman, Y. (1984b) Origin of embryonic signals allowing the establishment of pregnancy corpus luteum in ruminants. Proc. I0th Int. Congr. Anim. Reprod. \& A.I. Urbana 3, 509, Abstr.

Moor, R.M. \& Rowson, L.E.A. (1966a) The corpus luteum of the sheep: effect of the removal of embryos on luteal function. $J$. Endocr. 34, 487-502.

Moor, R.M. \& Rowson, L.E.A. (1966b) The corpus luteum of the sheep: functional relationship between the embryo and the corpus luteum. J. Endocr. 34, 233-239.

Northey, D.L. \& French, L.R. (1980) The effect of embryo removal and intrauterine infusion of embryonic homogenates on the lifespan of the bovine corpus luteum. J. Anim. Sci. 50, 298-302.

Ouchterlony, O. \& Nilsson, L.A. (1974). Immunodiffusion and immunoelectrophoresis. In Handbook of Experimental Immunology. Vol. I. Immunochemistry, pp. 19.1-19.39. Ed. D. M. Weir. Blackwell Scientific Publications, Oxford.

Roberts, B.E. \& Patterson, B.M. (1973) Efficient translation of tobacco mosaic virus RNA and rabbit globin 95 RNA in a cell-free system from commercial wheat germ. Proc. natn. Acad. Sci. U.S.A. 70, $2230-2234$.

Roberts, R.M., Buambach, G.A., Buhi, W.C., Denny, J.B., Fitzgerald, L.A., Babelyn, S.F. \& Horst, M.N. (1984) Analysis of membrane polypeptides by twodimensional polyacrylamide gel electrophoresis. In Molecular and Chemical Characterization of Membrane Receptors, pp. 61-113. Eds C. J. Venter \& L. C. Harrison. A. R. Liss, Inc., New York.

Roberts, R.M., Godkin, J.D., Bazer, F.W., Fincher, K.B., Thatcher, W.W., Knickerbocker, J.J. \& Bartol, F.F. (1985) Antiluteolysins produced by mammalian conceptuses. In Implantation of the Human Embryo, pp. 253-282. Eds R. G. Edwards, J. Purdy \& P. J. Steptoe. Academic Press, London.

Rowson, L.E.A. \& Moor, R.M. (1967) The influence of embryonic homogenates infused into the uterus on the lifespan of the corpus luteum in the sheep. $J$. Reprod. Fert. 13, 511-516.

Thatcher, W.W., Bazer, F.W., Sharp, D.C. \& Roberts, R.M. (1986) Interrelationships between uterus and conceptus to maintain corpus luteum function in early pregnancy: sheep, cattle, pigs and horses. $J$. Anim. Sci. 62 (suppl. II), 25.46. 